\title{
Naming sites: names as management tools in indigenous tourism sites - an Australian case study
}

This paper is concerned with the relationship between Australian Aboriginal art site names and tourist behaviour, and the extent to which naming is a management tool that can play a role in site protection. These issues will be explored through a case study of the ten public Aboriginal art sites in and around the Grampians-Gariwerd National Park in southwest Victoria, Australia. It was found that inappropriate names were contributing to visitor dissatisfaction which saw vandalism of directional signage and graffiti being left at some sites.

To understand the situation at the Grampians, it is necessary to overview the history of site nomenclature. There are over 110 Aboriginal art sites in and around the Grampians-Gariwerd National Park, however, only ten have been promoted as tourist sites. Until 1929, when Barrett and Kenyon, members of the ethnological section of the Royal Society of Victoria, began to take in active interest in Aboriginal sites, art sites were given names by locals who knew of their existence. For example, the first of the ten art sites is believed to have been 'discovered' by the European holder of 'Glenisla' station in 1859, and locals named the site 'Blackfellows Rock'.

In 1929, members of the ethnological section of the Royal Society of Victoria visited the site to obtain tracings for a model of the shelter that was to be shown at an exhibition of Aboriginal art planned to be staged later in the year at the National Museum of Victoria. From this visit, names such as 'Red Rock', 'Painted Rock', and 'Glen Isla Rock' began to be used. These naturalists learned of the existence of another art site during their 1929 visit. This site was known locally as the 'Cave of the Blood Red Hands'. Barrett (1929a) simultaneously named it 'Cave of Red Hands' and 'Red Hand Cave'; this was subsequently shortened to 'Cave of Hands'.

It is possible to identify two naming conventions in use during this period: names that were idiosyncratic or descriptive of the site or the dominant motifs found at the sites (names such as 'Red Hand Cave' where there are over 90 hand stencils in red ochre); or names that were locative, in that they referred to the location of the site (names such as 'Glen Isla Rock'). The descriptive 'cave' was used despite the fact that the bestowers of the names were aware that the sites were not caves but rock shelters (Barrett 1943a).

As art sites were progressively 'discovered' in the Grampians they were given a distinguishing name, often of a descriptive nature. However, this naming convention was abandoned in the early 1960s when a large number of sites were located along Cultivation Creek. Massola (1964) replaced the convention established by Barrett and Kenyon with a numerical system, that reflected the order of discovery; hence Cultivation Creek Shelter No. 1, Cultivation Creek Shelter No. 2, Cultivation Creek Shelter No. 3, and so on. One reason for the shift to a numerical system was the fact that more sites were being uncovered and it was becoming difficult to invent names for all of them, so it became more convenient to use a simple numbering system. This numerical locative naming system was continued by government agencies responsible for site management, and is still in use. 
By 1964, the year the tenth public art site became public knowledge, five sites had names that followed the numerical locative system, and five had idiosyncratic names. Of the ten, only two could in any way be seen to be derived from Aboriginal words: 'Bunjils Shelter' which takes its name from the spirit being that is represented at the site; and 'Camp of the Emu's Foot', which is a mistranslation of Jananginj Njaui, the traditional Jardwadjali name of Victoria Gap, which actually means 'the sun will go'. 'Brimgower Shelter', an alternative name for the site named 'Cave of Fishes' is an Aboriginal place name meaning 'mountain spring'. Although Massola (1957) was aware that art sites were rock shelters and not 'caves', he continued to use the established names 'because the localities have long been called such'.

The first concerted moves to change the names of art sites in the Grampians began in 1984, when the National Parks Service commenced preparing a management plan for the proposed Grampians National Park. In 1984, Gunn, a rock art consultant, recommended changes be made to the names of nine of the ten public sites. 'Bunjils Shelter' was excluded from his recommendations because it already had an Aboriginal name. Gunn noted that the variety of site names had led to a degree of confusion; he argued that presently accepted names were either misleading or decidedly Eurocentric, or both. For instance the term 'cave' was misleading for sites that were only shallow rock overhangs. Similarly Eurocentric descriptive names, such as 'Cave of Ghosts', for a site with white pipeclay human figures, often conjured up inappropriate expectations in visitors that lead to disappointment, ridicule, and vandalism. He recommended that new names should either be tied to place or 'objective' description, rather than interpretation of content or meaning. Given that the sites had been used by Aboriginal people as sheltering places, he proposed sites be suffixed with 'Aboriginal Shelter'.

In 1985 Gunn refined his 1984 paper and of the nine sites he recommended that six should have names conferred on them taken from adjoining Aboriginal place names. Of the remaining three, he recommended they be given names taken from local Aboriginal vocabularies that describe the major motifs found at these sites.

With the release of the Grampians National Park Management Plan in 1985, it was acknowledged that some of the names of the public art sites in the National Park were misleading or confusing to the public. It was proposed that interpretation at these sites would 'reduce confusion resulting from the current names of the sites. More appropriate names may be used in site interpretation in conjunction with the current names'.

The need to take some action to confer more appropriate site names was reinforced by a preliminary assessment of graffiti at art sites in 1987 (Hough and Conole 1987). Hough and Conole noted the influence of the site name 'Cave of Fishes' in the kind of graffiti that was occurring at the site; for example, vandals had scratched fish silhouettes and 'shark jaw' cartoons into the rock face. One person had renamed the site 'Cave of Jaws'. Barrett (1943a,b) had named this site 'Cave of Fishes' because some of the motifs at the site were taken to represent small fish found in nearby Cultivation Creek. Barrett pronounced the motifs to be hardyhead, a small freshwater fish. These motifs, initially taken to be fish, were later taken to be elongated human figures. Hall, another rock art consultant, believed that tourists, in their annoyance at not seeing fish, had scratched drawings of fish into the rock. The name had conjured up false expectations as people set out to visit the site, which often resulted in disappointment when they reached their destination. 
Graffiti at Larngibunja Shelter, formerly known as 'Cave of Fishes' date from November 1942, when Arthur Mathew, a local landholder visited the site and left 'A. Mathew 19/11/42' on the rock face. These graffiti still existed in 1987. Hough and Conole found on inspecting this site in 1987 that because of the hard shelter surface most drawn graffiti occurred as scratches. Two unusual features of the graffiti at this site was the number of fish silhouettes and 'shark jaw' cartoons and the well punctuated prosaic comment 'We came to see this too. Dont feel bad about it!' The shark jaw cartoons were obviously a reference to the series of horror films about predatory sharks Jaws (1975), Jaws 2 (1978), Jaws 3-D (1983), and Jaws the Revenge (1987). A number of dated names were also present: 'A. Mathew 19/11/42', 'A.H. Marshall 1962', and 'Bob Hiatt 1969'. Scratched designs and representations of a human figure were present. They estimated that approximately 100 incidents of graffiti were at this site.

A survey of visitors to art sites in and around the Grampians National Park in 1987 (Gale and Gillen 1987) recommended that all sites be given names which were consistently used on maps and road signs. Gale and Gillen identified the confusing and inappropriate names of sites as one of the most pressing problems affecting the dissatisfaction of visitors. They noted that naming was contradictory and confusing and recommended that each site name include the words 'Aboriginal Art Shelter', and that the term 'Cave' not be ascribed to any site as it leads to confusion with the identification of the art site.

In March 1989, the Victorian Tourism Commission announced its intention to restore Aboriginal place names in and around the Grampians National Park and to confer more appropriate names on the public art sites. In May 1990, Brambuk Incorporated, representing the five relevant Aboriginal community groups with a stake in the management of the National Park, and the Victorian Tourism Commission presented the Place Names Committee of Victoria with a submission calling for the restoration of Jardwadjali and Djabwurrung place names for rock art sites and landscape features in and around the Grampians National Park (Clark and Harradine 1990).

The Clark and Harradine (1990) submission, in relation to rock art nomenclature, was the culmination of Gunn's efforts to have more appropriate names conferred on art sites - efforts he had begun in late 1984. The submission proposed to confer names that no longer contained the misleading cave, and were taken from nearby named features or were named after the dominant motifs found at the site.

The commitment to confer more appropriate names on rock art sites recognised that names are a management tool and that they play a role in site protection. As noted by Hough and Conole (1987), inappropriate names had resulted in graffiti at some sites, and by assigning more appropriate names it was expected that such behaviour would not be repeated. One senior administrator in a government land management agency put the view for changing the names in the following way:

The names that are based on incorrect or outdated European interpretations are misleading and in some cases may increase the threat to the continued preservation of the art. Many of these names use the word 'cave' when in fact the art is located in small rock overhangs or shelters. Visitors to these sites are often disappointed when the 'cave' turns out to be a shallow alcove. Their disappointment is often compounded by the absence of any apparent link between the art and images conjured up by the site's name. The results of this disappointment are only too apparent at 
'Cave of Fishes' where tourists have scratched drawings of fish into the rock in an expression of annoyance at not seeing any Aboriginal drawings of fish. The graffiti at other sites, 'Cave of Ghosts' in particular, probably results from similar motivation. The replacement of these names should be given high priority (Buxton n.d. in Clark 1991).

After considerable public debate about the proposal to reinstate indigenous place names and confer more appropriate rock art site names, all nine art sites names were changed, and with one minor amendment, the recommendations of the Clark and Harradine submission were formally adopted.

To understand the place and function of site names Leiper's (1995) 'tourist attraction system' is invaluable. In the case of rock art tourism, Leiper's attraction system would have the following elements: a tourist or human element, a nucleus or central element - in this case a rock art site; and a marker or informative element - in this case the name of the site. Markers are defined as items of information or image, about central elements, as received by tourists. Markers are not the media conveying information; they are not the signposts but the signs. Markers may be 'on-site' and 'off-site' (away from the object of sightseeing).

Site names, as markers, may be conveyed to tourists on brochures and on maps. People planning to visit the Grampians-Gariwerd National Park acquire knowledge about the park through diverse media, including television, radio and newspapers, from travel guides or from tourist information centres. From these media, knowledge about rock art sites may be obtained and the intention formed to visit a number of sites in the park.

In the case of rock art sites, site names function as markers that link tourists to the central elements - the art sites. Because markers function to trigger motivation they often contain information or present an image about what might be experienced at the sites concerned. In the case of a site named 'Cave of Ghosts' the name as a marker is likely to convey several messages that relate to the physical characteristics of the site and the nature of the experience that can be expected there. The fact that the site is not a cave indicates that the marker is deficient.

Another central function of markers is that they enable tourists to form images. Names of nuclei often have positive connotations that affect tourists' attitudes and the images they form about certain places. This may contribute to motivation and add to satisfaction. Names like Costa del Sol ('Coast of the Sun') and Surfers Paradise both create positive connotations and have appeal to target markets.

MacCannell (1976) has suggested that attractions develop in identifiable phases. The first phase is that of naming. He argues that as sightseeing objects or sites become the focus of visitors they are given names 'as the first phase of sight sacrilization' (MacCannell 1976: 44). As visitation increases the site is framed off and displayed more prominently, a phase he called 'framing and elevation'. If visitation continues to increase the site may acquire a sacred reputation, which he calls 'enshrinement'. The fourth phase is that of 'duplication' in which copies or replicas or pictures of the nucleus are made available to tourists.

In the case of indigenous rock art sites, which are taken to be sacred sites/sights, MacCannell's description has considerable currency. In the case of the ten public rock art sites in the Grampians-Gariwerd National Park, many have gone through this four 
phase process. However, as seen by the above discussion, many have failed to create the atmosphere that would be expected from such ancient places.

Gunn (1972) has identified the areas surrounding the nuclei or central elements of attractions as comprising two environmental zones he has called 'inviolate belts' and 'zones of closure'. The inviolate belt is the area immediately around a nucleus, through which tourists enter the nucleus and here is the location of 'physiopsychological conditioning and reflecting' as the 'mental set or anticipation of the attraction has much to do with their reception and approval when the feature is reached' (Gunn 1972:40-41). The inviolate belt includes such things as the entrance path, viewing platforms, and protective grilles that enclose the art on the rock face of the shelters. The inviolate belt corresponds to MacCannell's 'enshrinement' concept. The zone of closure refers to the area immediately outside the inviolate belt, and in the case of rock art sites is where the tourist support facilities and services such as car parks, toilets, picnic areas, on-site interpretation, and directional signage, are located.

From the viewpoint of both the theories and models of Gunn, Leiper and MacCannell the public rock art sites at the Grampians-Gariwerd National Park were failing as tourist attractions because of several factors. Until the recent changes to site names, many of the rock art site names were found to be dysfunctional. The mental set of anticipation these names produced often did not match the physical setting of the art sites and the atmospheres tourists expected to experience did not match their expectations. Some tourists vented their frustration by either vandalizing the signage, often leaving messages on directional signage in visitor car parks informing other tourists not to expect too much at the sites, or venting their displeasure at the site by vandalizing the rock face itself.

Naming, as an important first step in place making and the sacrilization of sights or sites, plays a vital role in the development of tourist attractions. If the names of sites are dysfunctional and fail as informative markers and conjure expectations that are not met, then names can become management problems and contribute to graffiti, vandalism and destruction and negative word of mouth publicity. In the case of tourist sites that have a long history of visitation and which have names that were bestowed at times when knowledge of site management was poorly understood, site managers have a clear responsibility to reevaluate the basis of their naming practices and if necessary institute a process of renaming and remarking of important cultural sites. 


\section{REFERENCES:}

Barrett, C. 1929. 'Cave hunting and what we found' in Australian Museum Magazine, 3 (12), pp. 414-419.

Barrett, C. 1943a. 'New primitive are gallery’ in Wildlife, 5 (4), pp. 124-126

Barrett, C. 1943b. 'Aboriginal art galleries' in C. Barrett \& R.H. Croll (eds.) Art of the Australian Aborigines, Bread and Cheese Club, Melbourne, pp 37-58.

Clark, ID. \& Harradine, L.L. 1990. The Restoration of Jardwadjali and Djabwurrung names for rock art sites and landscape features in and around the Grampians National Park, A submission to the Place Names Committee on behalf of Brambuk Inc. and the Koorie Tourism Unit, Victorian Tourism Commission, Melbourne.

Clark, ID. 1991, 'A history of rock art site management in the Grampians National Park and Environs', an unpublished report to the Victoria Archaeological Survey.

Gale, F. \& Gillen, J. 1987. 'Visitor survey of Aboriginal art sites within and adjacent to Grampians National Park', unpublished preliminary report, April, 25pp.

Gunn, C. 1972. Vacationscape: Designing Tourist Regions, Van Nostrand Reinhold, New York.

Gunn, R.G. 1984. 'Recommended changes to Aboriginal site names in the Grampians’, unpublished report, December, 2pp.

Gunn, R.G. 1985. 'Recommended changes to Aboriginal site names in the Grampians’, unpublished report, February, 3pp.

Hough, D. \& Conole, L. 1987. A preliminary assessment of graffiti at art sites in the Grampians, Victoria Archaeological Survey Internal Working Document 1987/2, March, 17pp.

Leiper, N. 1995. Tourism Management, RMIT Press, Collingwood.

MacCannell, D. 1976. The Tourist: A New Theory of the Leisure Class, Shoken, New York.

Massola, A.S. 1957. 'Bunjils Cave Found’ in Victoria Naturalist, 74, pp. 19-22.

Massola, A.S. 1964. 'Aboriginal Relics in Victoria', unpublished paper, National Museum of Victoria, 3pp. 